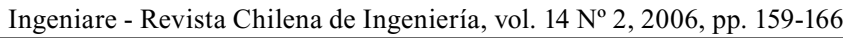

\title{
TRANSFORMATIONAL AND TRANSACTIONAL LEADERSHIP: A STUDY OF THEIR INFLUENCE IN SMALL COMPANIES
}

\section{LIDERAZGO TRANSFORMACIONAL Y TRANSACCIONAL: UN ESTUDIO DE SU INFLUENCIA EN LAS PEQUEÑAS EMPRESAS}

\author{
Liliana Pedraja-Rejas $^{1} \quad$ Emilio Rodríguez-Ponce $^{1} \quad$ Milagros Delgado-Almonte $^{1} \quad$ Juan Rodríguez-Ponce $^{1}$ \\ Recibido el 9 de septiembre de 2005, aceptado el 17 de enero de 2006 \\ Received: September 9, 2005 Accepted: January 17, 2006
}

\begin{abstract}
RESUMEN
Este trabajo tiene como objetivo principal descubrir si existe o no influencia de los estilos de liderazgo sobre el desempeño en las pequeñas empresas. Para este efecto se trabaja con la tipología de liderazgo transformacional, liderazgo transaccional y el estilo laissez faire con una muestra de 96 gerentes de pequeñas empresas del norte de Chile.

Los resultados observados indican que el estilo de liderazgo transformacional se presenta en un bajo grado en las empresas en estudio, mientras que el estilo transaccional se presenta en un alto grado en las organizaciones estudiadas y el estilo laissez faire es muy poco frecuente.
\end{abstract}

Asimismo, considerando los efectos del liderazgo sobre la eficacia de las pequeñas empresas analizadas, se observa que el liderazgo transformacional tiene un impacto positivo sobre la eficacia, en tanto que el liderazgo transaccional y laissez faire tienen un impacto negativo.

Palabras clave: Dirección estratégica, liderazgo transaccional, liderazgo transformacional, liderazgo laissez faire, pequeña empresa.

\section{ABSTRACT}

This work aims at finding out whether or not leadership style influences the performance of small firms. To this purpose, the study utilized the categories of transformational, transactional leadership and laissez faire style, with a sample of 96 managers of small companies in the north of Chile.

The results obtained show that, in the organizations studied, transformational leadership is moderate, whereas the transactional style is frequent and laissez faire style is infrequent.

Similarly, with regard to the effects of leadership on the effectiveness of the small companies analyzed, it was found that transformational leadership has a positive impact on performance, whereas transactional leadership and laissez faire style had a negative impact.

Keywords: Strategic management, transformational leadership, transactional leadership, laissez faire leadership, small business.

\section{INTRODUCTION}

Organization outcomes (i.e. strategic decisions and performance), are partially predetermined by the features of those who participate in administration [19].
This work was based on the premise that in a context of limited rationality, the field of view is limited by the cognitive base and values, thus influencing selective perception and interpretation, and hence management perception and strategy selection.

\footnotetext{
1 Universidad de Tarapacá. Av. 18 de Septiembre2222 Arica, Chile.1pedraja@uta.cl,erodrigu@uta.cl, mdelgado@uta.cl,jrodriguez@gmail.com
} 
There are several studies that have supported this view, demonstrating that diversity [33], [36], [11], leadership style [16], [28], [39], [31] and top-management team size [18], [1] are variables that can influence the decisionmaking processes, and consequently, the effectiveness of the organization.

Contrarily, the Ecology of Organizations proposes that there is a process of natural selection for the "species" of organizations, which implies that the environment determines who will survive. According to this theory, the top management team will be composed of passive agents with a minimum impact on corporative development [20], [2], [3], [12].

The present research is focused on discovering whether or not there is any statistically significant relationship between leadership style and effectiveness of small organizations in the Tarapacá region of Chile.

\section{CONCEPTUAL FRAMEWORK}

\section{Leadership}

Since the 1980s, most research on leadership has focused on the characteristics of the leader and his effects on the organization [4], [24], [37]. Bass' theory provides a basis for the present study: it states that in transformational leadership, the leader motivates followers by inspiring them, setting challenges and motivating personal development. Transformational leadership encourages the achievement of high collective standards, through a sense of purpose and a common mission and vision. The second leadership style is transactional, in which the leader motivates his followers via specific benefits provided that they are capable of accomplishing the tasks assigned to them. The transactional style involves negotiation between the leader and subordinates. There is also the "laissez faire" leadership style, in which the leader rejects control and allows subordinates to take the decisions [5].

\section{Effects of Different Leadership Styles}

The Upper Echelons Theory [19] presents an alternative paradigm to that presented by the Ecology of Organizations theory: it presents a set of variables as explanations for the performance of organizations. Here we are going to focus on the variable of leadership style, and how it has been considered in the existing literature on Business Management.

In particular, it has been argued that leadership style should be included in the Upper Echelons Theory [39] because it has direct effects on the decision making process and on the results of organizations.

Similarly, other studies have confirmed that leadership style affects group work processes, the social climate and results. From this perspective, leadership style affects the climate, and the climate affects creativity and productivity, although leadership can also affect productivity directly [23], [16].

Likewise, it has been proposed that different leadership styles have diverse effects on variables such as flexibility, responsibility, standards, rewards, clarity and commitment, and in some cases, on the organizational climate [17].

In order to understand this, it must be recognized that leadership style influence subordinates [35], since the leader's behaviour produces reward mechanisms that affect the behaviour of individuals in the organization.

Additionally, it has been shown that gender is related to leadership style, and that it also influences decisionmaking style [30].

In a similar manner, it has been shown that the performance of an organization is influenced by the competitive and innovative culture, and that the culture is influenced by the leadership style. Thus the performance of an organization is influenced by the leadership style via its culture [28].

In support of the studies mentioned so far, research has been carried out which has shown that leadership style, the processes, the produces and the services, as well as the people and client focus, explain the results of organizations [34].

It is important to note that there are different styles of leadership [9], [25], [22], and that it is difficult to establish the supremacy of one particular type.

In terms of performance, it has been postulated that the definition of leadership style with regard to a particular decision requires the analysis of a group of factors such as: the relevance of the decision, the importance of the commitment, the likelihood of success, the experience of the leader and of the group, the group's support for achieving the objectives, and the competence of the team [38].

More recently, it has been indicated that leadership styles are relevant in public organizations, given that they influence the effectiveness of such organizations [31]. 
The discussion above establishes a clear need to include leadership style as a determinant in the effectiveness of organizations. The distinctive features of small companies that distinguish them from large and mediumsized companies must also be pointed out.

\section{Enterprise Size}

Company size is considered to be a fundamental feature with important implications for the strategic behaviour of organizations.

Although there are no strict rules for classifying the size of organizations, the Development Corporation of Chile (CORFO-Chile) criterion suggests that companies with between 10 and 50 employees can be considered as small companies in this country.

In general terms, the size of an organization can have economic and financial effects. For example, it has been proposed [15] that the distribution of different sized organizations in the manufacturing industry in the United States of America is explained by considering the effectiveness of large and small organizations [15]. The main argument of the author is that large companies are more effective since they generate scale of economies, and that this is a fundamental variable in the explanation of the distribution in the economic sector. Likewise, from an economic and financial point of view, it has been demonstrated [8] that smaller companies have higher patrimonial costs due to their greater risk levels and lower liquidity of shares.

However, it must be recognized that it is not only economic and/or financial differences that arise from differences in the size of organizations, but that the size of an organization also influences the decision-making process.

A germane study with regard to the effects of size was [26] carried out with multiple methods over three years to study decision making, and found that in small firms decisions are generally taken by one person, normally the owner, whereas in larger companies decisions are taken by the top management team. Furthermore, management style and relations with employees are more informal in small organizations than in bigger ones.

The centralization of decision-making is another distinguishing feature of small organizations, as confirmed by an in-depth study [10] of 16 small organizations. It was concluded that decision making is limited by time and by the desire of the owner(s) to retain control.
Other studies [21], [14] have also contributed to the claim that organization size is a determinant in decisionmaking processes. The former study revealed that there are contingency variables associated with firm size that impact the decision-making process, even to the same extent as the environment, and thus the effectiveness. In the latter study, the authors concluded that the characteristics of the industrial sector are determinants of strategic behavior, although this behavior is also influenced by the company's size.

In a related study [13] of small and large airlines in the USA the authors discovered differences in the strategic reactions of the two types of airlines with regard to the speed of announcement and visibility of the strategic behavior. They also found that the speed with which decisions are made is a relevant determinant of effectiveness in small firms, whereas in large firms the propensity to act or react to strategic answers is relevant.

Small firms have particular problems connected to their size that large firms do not have to confront. For example, a study [29] of small and medium-sized firms concluded that the growth of small firms is more dynamic, and not lineal, i.e. they do not systematically generate profits. It was also found that the existence of a business plan is positively correlated with economic results, and that the types of problems that management have to deal with are related to the size of the organization.

Differences in strategic behavior that are linked to size have been identified, even within groups of small organizations. For example, it has been established [40] that the larger small organizations exhibit strategic behavior that is consistent with their resources and capabilities, whereas this is not the case in very small organizations.

The differences in strategies that are linked to size have been expounded [27], and it has been shown that while there is no relation between firm size and results in export management, there is a difference in the basis of competitive advantage and the reasons for which companies decide to export.

In conclusion, the set of studies examined here confirm that a firm's size will impact its economic, financial and strategic attributes, and, in particular, its decision making process. Furthermore, from a theoretical point of view, it must be considered that small firms have several features that distinguish them from large firms, which influence the strength of the relationship between leadership style and effectiveness. 


\section{HYPOTHESES}

This study presents the following alternatives hypotheses:

Upper Echelons Theory:

- Transformational leadership influences the effectiveness of small companies.

- Transactional leadership influences the effectiveness of small companies.

- Laissez faire style influences the effectiveness of small companies.

Ecology of Organizations:

- Transformational leadership does not influence the effectiveness of small companies.

- Transactional leadership does not influence the effectiveness of small companies.

- Laissez faire style does not influence the effectiveness of small companies.

\section{METHODOLOGY}

\section{Sample}

A questionnaire was given to 318 managers from small organizations in the Tarapacá region in the north of Chile.

In order to encourage the directors to complete the questionnaire, they were contacted a maximum of three times each. The questionnaire was answered by 96 $(30.2 \%)$ of the managers.

\section{Unit of Analysis}

The manager's behaviour was analyzed with regard to the formulation and implementation of the most recent strategic decision taken and carried out by the company.

\section{Variables and Measures}

Leadership styles:

A set of variables was considered and a set items was adapted according to [4], [7]. A resume is given below:

- Transformational Leadership

In the most recent strategic decision taken and implemented:
- The leader shared the mission and vision of the institution with his followers.

- The followers understood and shared the aims of the leader.

- The followers shared and accepted the long-term vision of the leader with enthusiasm.

- The followers shared and accepted with enthusiasm the challenges pertaining to their professional development and fulfilment that arose from the strategic decision.

- The followers shared and accepted their role in the organization with enthusiasm.

- Transactional Leadership

In the most recent strategic decision taken and implemented:

- The followers understood and agreed with the rewards system that emanated from the strategic decision.

- The followers understood and shared the systems of power within the organization.

- Negotiation and the definition of clear exchange relationships are crucial for the development of long- and short-term work.

- "Laissez faire" Leadership

In the most recent strategic decision taken and implemented:

- The leader completely delegated the formulation of the decision to his subordinates.

- The leader completely delegated the implementation of the decision to his subordinates.

\section{Effectiveness:}

In order to measure effectiveness [31], [32], the importance of a set of factors was established and then the success level of the organization with regard to each factor was evaluated by calculating an effectiveness value on a scale of 1 to 100 .

\section{Validity and reliability of variables and measures}

To assess validity, and, in particular, reliability, Cronbach's Alpha was calculated with the following results. 
Table 1. Effectiveness factors.

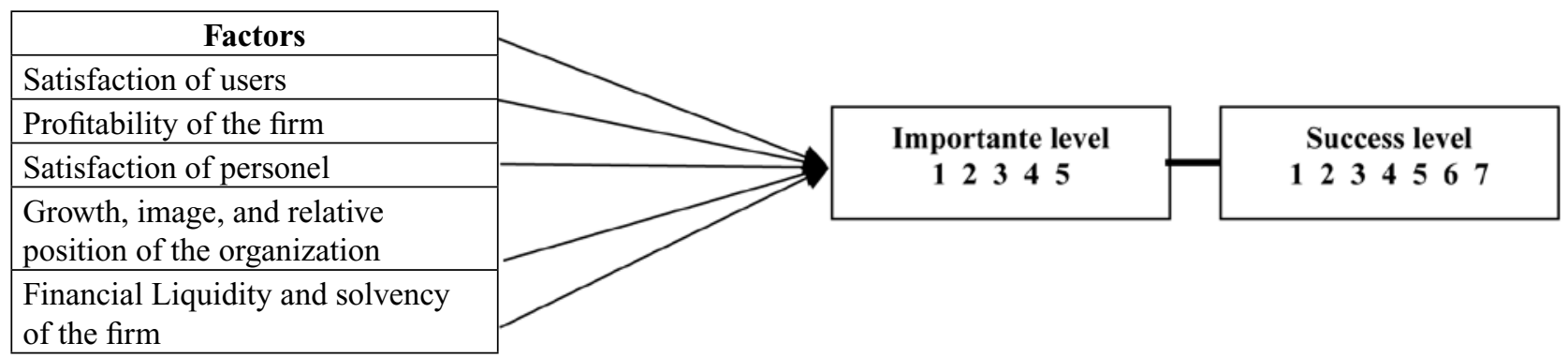

Table 2. Reliability of the Variables.

\begin{tabular}{|c|c|c|}
\hline Variables & Cronbach's Alpha & Reliability \\
\hline Transformational Leadership & 0.74 & Good reliability \\
\hline Transactional Leadership & 0.72 & Good reliability \\
\hline Laissez Faire Leadership & 0.88 & Very good reliability \\
\hline Effectiveness & 0.71 & Good reliability \\
\hline
\end{tabular}

\section{RESULTS}

The following results were obtained from this study:

\section{Dimensions of Leadership Style}

Analysis of the questionnaires gave the following results, table 3 .

From a statistical t-test, it can be stated that:

- Transformational leadership is present to a moderate degree in the small companies studied $($ Ho: Mean $=4.0, \mathrm{t}$ test $=1.75$ )

- Transactional leadership is more than moderately frequent in the small companies studied (Ho: Mean $=4.0$, $\mathrm{t}$ test $=6.07$ )

- Laissez Faire leadership is relatively infrequent in the small companies studied (Ho: Mean $=4.0, \mathrm{t}$ test $=-119.90)$.

\section{Effectiveness and leadership style}

The following multiple linear regression model was used:

$$
\begin{aligned}
\text { Eficacia } & =\mathbf{A}+\mathbf{B} 1 * \text { L.TRANSF }+ \\
& + \text { B } 2 * \text { LTRANSAC. }+ \text { B3 } * \text { L.L.F. }+ \text { Ei }
\end{aligned}
$$

Where:

$\begin{array}{ll}\text { L.TRANSF } & \text { : Transformational Leadership } \\ \text { L.TRANSAC } & \text { : Transactional Leadership } \\ \text { L.L.F. } & \text { : Laissez Faire Leadership }\end{array}$

A Pearson correlation matrix shows the following results, table 4 .

The regression model presents the following results, table 5 .

Thus, it can be stated that:

- There is a positive and significant correlation between effectiveness and transformational leadership.

- There is a negative and significant correlation between effectiveness and transactional and laissez faire leadership styles, although it must be recognized that the last one was very infrequent in the sample studied.

- $28.4 \%$ of the variation can be explained by the regression model used. There is also significant evidence that variables have been omitted ( $t$ test of the constant $=11.053$ ). 
Table 3. Descriptive Statistics.

\begin{tabular}{|l|c|c|c|c|}
\hline Model & Non standardized beta & Standard error & Test $\mathrm{t}$ & $\mathrm{R}^{2}$ adjusted \\
\hline Constant & 97.23 & 8.797 & 11.053 & \\
\hline Transformational Leadership & 3.190 & 0.740 & $4.312^{* * *}$ & \\
\hline Transactional Leadership & -3.049 & 0.962 & $-3.171^{* * *}$ & \\
\hline Laissez Faire Leadership & -10.079 & 5.356 & $-1.882^{* *}$ & \\
\hline $\mathrm{R}^{2}$ adjusted & & & & 0.284 \\
\hline
\end{tabular}

*** Significant correlation to $1 \%$

** Significant correlation to $5 \%$

Table 4. Pearson Correlation Results.

\begin{tabular}{|l|c|c|}
\hline \multicolumn{1}{|c|}{ Variables } & Mean & Standard Deviation \\
\hline Transformational Leadership & 4.32 & 1.79 \\
\hline Transactional Leadership & 4.85 & 1.37 \\
\hline Laissez Faire Leadership & 1.06 & 0.24 \\
\hline Effectiveness & 84.51 & 12.89 \\
\hline
\end{tabular}

Table 5. Regression Model Results

\begin{tabular}{|l|c|c|c|c|}
\hline \multicolumn{1}{|c|}{ Variables } & Effectiveness & L.TRANSF & L.TRANSAC & L.L.F \\
\hline Effectiveness & 1.000 & $0.454^{* * *}$ & $-0.349^{* * *}$ & $-0.209^{* *}$ \\
\hline L.TRANSF & & 1.000 & -0.182 & -0.119 \\
\hline L.TRANSAC & & & 1.000 & -0.004 \\
\hline L.L.F & & & & 1.000 \\
\hline
\end{tabular}

*** Significant correlation to $1 \%$

** Significant correlation to $5 \%$

\section{CONCLUSIONS}

From this study the following conclusions can be drawn:

- There is a dominance of the transactional leadership style over transformational and laissez faire styles.

- Leadership style influences the effectiveness of the small companies studied. This influence is positive in the case of transformational leadership and negative in the cases of transactional and laissez faire leadership.

- From these observations of small companies, the following suggestions can be made for the formulation and implementation of decisions:

- The leader should share the vision and mission of the institution with his followers;

- The followers should understand and share the leader's aims;

- The followers should share and accept the leader's long-term vision;
- The followers should share and accept the challenges pertaining to their professional development and fulfilment that arise from the strategic decision.

- The followers should share and accept their role in the organization.

- This study was of exploratory nature and obviously is not conclusive. However, it contributes empirically to the development of best practice in small companies.

\section{REFERENCES}

[1] A. Amason, H. Sapienza. "The effects of top management size and interaction norms on cognitive and affective conflict". Journal of Management, Vol. 23. No 4, pp. 495-517. 1997.

[2] T. Amburgey, H. Rao. "Organizational ecology: Past, present and future directions". Academy of Management Journal. Vol. 39. $\mathrm{N}^{\mathrm{o}}$ 2, pp. 12651286, 1996. 
[3] J. Baum, C. Oliver. "Toward an institutional ecology organizational founding". Academy of Management Journal, Vol. 39. $\mathrm{N}^{\mathrm{o}}$ 2, pp. 13791427. 1996.

[4] B. Bass. "Leadership and Performance Beyond Expectations". The Free Press. New York. 1985.

[5] B. Bass. "From transactional to transformational leadership: Learning to share the vision". Organizational Dynamics. Vol. 18, pp. 19-31. 1990

[6] B. Bass. "A new paradigm of leadership: An inquiry into transformational leadership" Alexandria, VA: U.S. Army Research Institute for the Behavioral and Social Sciences. 1996.

[7] B. Bass, B. Avolio. "Multifactor leadership questionnaire: Sampler set". Redwood City. CA: Mind Garden. 1995.

[8] W. Beedles. "Small firms equity cost: evidence from Australia". Journal of Small Business Management. Vol. 30. № 3, pp. 57-66. 1992.

[9] D. Bourantas, V. Papadakis. "Greek management". International Studies of Management \& Organization. Vol. 26. № 3, pp. 13-33. 1996.

[10] T. Byers, T. Slack. "Strategic decision-making in small business within the leisure industry". Journal of Leisure Research. Vol. 33. No 2, pp. 121-136. 2001.

[11] M. Carpenter, J. Fredrickson. "Top management teams, global strategy posture and moderating role of uncertainty". Academy of Management Journal. Vol. $44 \mathrm{~N}^{\mathrm{o}}$ 1, pp. 533-545. 2001.

[12] E. Carroll, M. Hannan. "The Demography of Corporations and Industries". Long Range Planning. Vol. $33 \mathrm{~N}^{\mathrm{o}}$ 4, pp. 608. 2000.

[13] M. Chen, D Hambrick. "Speed, stealth and selective attack: how small firms differ from large firm in competitive behavior". Academy of Management Journal. Vol. 38. $\mathrm{N}^{\mathrm{o}}$ 2, pp. 453-482. 1995.

[14] T. Dean, R. Brawn y C. Bamford. "Differences in large and small firms responses to environmental context: strategic implications from a comparative analysis of business formations". Strategic Management Journal. Vol. 19, pp. 709-728. 1998.
[15] E. Eckard. "Plant-level scale economics and industrial concentration". Quarterly Review of Economics and Finance. Vol. 34. $\mathrm{N}^{\mathrm{o}}$ 2, pp. 173. 1994.

[16] G. Evkall, L. Ryhammar. "Leadership style, social climate and organizational outcomes: A study of a Swedish University College". Creativity and Innovation Management. Vol. 7. $\mathrm{N}^{\mathrm{o}} 3$, pp. 126130. 1997.

[17] D. Goleman. "Leadership that gets results". Harvard Business Review. Vol. 78. $\mathrm{N}^{\mathrm{o}}$ 2, pp. 78-90. 2000.

[18] J. Haleblian, S. Finkelstein. "Top management team size, CEO dominance and firm performance". Academy of Management Journal. Vol. 36. $\mathrm{N}^{\circ} 4$, pp. 844-863. 1993.

[19] D. Hambrick, P. Mason. "Upper echelons: The organization as a reflection of its top managers". Academy of Management Review. Vol. 9. No 2 , pp. 193-206. 1984.

[20] M. Hannan, J. Freeman. "The population ecology of organizations". American Journal of Sociology. Vol. $82 \mathrm{~N}^{\mathrm{o}}$ 5, pp. 929-963. 1977.

[21] S. Hart, C. Banbury. "How strategic making processes can make a differences". Strategic Management Journal. Vol. 15, pp. 251-269. 1994.

[22] O. Ingers. "Viewpoint: A leader's inner security might be a crucial factor for choice of leadership style". Journal of European Industrial Training. Vol. 19, No 4, pp. 19-20. 1995.

[23] S. Kahai, J. Sosik. "Effects of leadership style and follower's cultural orientation on performance in group and individual task conditions". Personnel Psychology. Vol. 50. No 1, pp. 121-147. 1997.

[24] S. Kanungo. "User development and systems development for networked systems in small organizations". International Information Management Conference Proceedings. California State University. San Bernardino. 1990.

[25] K. Lowe, G. Galen. "Effectiveness correlates of transformational and transactional leadership: A meta-analytic review of MLQ literature". Leadership Quarterly. Vol. 7. No 3, pp. 385-426. 1996. 
[26] H. Matlay. "Employee relations in small firms", Employee relations. Vol. 21, No 3, pp. 285-296. 1999.

[27] O. Moen. "The relationship between firm size, competitive advantages and sport performance revisited". International Small Business Journal. Vol. 18, No 1 , pp. 53-72. 1999.

[28] E. Ogbonna, L. Harris. "Leadership style, organizational culture and performance: Empirical evidence from U.K. companies". International Journal of Human Resource Management. Vol. $11 \mathrm{~N}^{\circ} 4$, pp. 766-788. 2000.

[29] B. Orser, S. Hogarth-Scott y A. Riding. "Performance, firm size, and management problems solving". Journal of Small Business Management. Vol. 38. No 4, pp. 42-58. 2000.

[30] D. Park. "Gender role, decision style and leadership style". Women in Management Review. Vol. 11. No 8, pp. 13-17. 1996.

[31] L. Pedraja, E. Rodríguez. "Efectos del estilo de liderazgo sobre la eficacia de las organizaciones públicas". Rev. Fac. Ing. - Univ. Tarapacá. Vol. 12 $\mathrm{N}^{\mathrm{o}}$ 2, pp. 63-73. 2004.

[32] L. Pedraja, E. Rodríguez. "Organizational Performance on Public Administration and leadership style effects". Conference Proceedings International Business Association. Vancouver. Canada, pp. 120-127. 2005.

[33] L. Pelled, K. Eisenhardt y K. Xin. "Exploring the black box: An analysis of work group diversity, conflict, and performance". Administrative Science Quarterly. Vol. 44 No 1, pp. 1-28. 1999.
[34] S. Rahman. "Total quality management practices and business outcome: Evidence from small and medium enterprises in Western Australia". Total Quality Management. Vol. 12 No 2, pp. 201-210. 2001.

[35] B. Shamir, R. House, y M. Arthur. "The motivational effects of charismatic leadership: A self-concept based theory". Organization Science. Vol. 4 No 4, pp. 577-594, 1993.

[36] T. Simonds, L. Pelled, y K. Smith. "Making use of difference: Diversity, debate and decision comprehensiveness in top management teams". Academy of Management Journal. Vol. $42 \mathrm{~N}^{\mathrm{o}} 6$, pp. 662-673. 1999.

[37] N. Tichy, M. Devanna. "The transformational leader”. New York. John Wiley \& Sons. 1990.

[38] V. Vroom. "Leadership and decision making process", Organizational Dynamics. Vol. 28 $\mathrm{N}^{\mathrm{o}} 4$, pp. 82-94. 2000.

[39] D. Waldman, G. Ramírez, R. House, y P. Puranam; "Does leadership matter, CEO leadership attributes and profitability under conditions of perceived environmental uncertainty". Academy of Management Journal. Vol. 38. No 4, pp. 943974. 2001.

[40] J. Wolff, T. Pett. "Internationalization of small firms: An examination of export competitive patterns, firm size, and export performance", Journal of Small Business Management. Vol. 38, $\mathrm{N}^{\mathrm{o}} 4$, pp. 34-47. 